\title{
ENTREVISTA MÔNICA FRANCISCO
}

Entrevistar a deputada estadual(PSOL) e cientista social, nascida e criada no Morro do Borel, no bairro da Tijuca (RJ), ex-assessora da vereadora Marielle Franco, Mônica Santos Francisco tem um importante papel para este dossiê em razão de sua atuação na Assembleia Legislativa do Rio de Janeiro (Alerj), em que representa esses vários lugares de fala como mulher negra e favelada, pastora, cientista social e deputada eleita em 20I8. Mônica Francisco conversou com Itamar Silva, membro do grupo Eco e da Universidade da Cidadania (UC/UFRJ), e Sarah Silva Telles, professora do Departamento de Ciências Socias da Pontifícia Universidade Católica do Rio de Janeiro (PUC-Rio).

Entrevistadores: Na sua longa biografia como mulher negra, nascida na favela do Borel, militante, pastora, cientista social e deputada estadual, pediríamos que você começasse contando sua história.

Mônica Francisco: Primeiro, gostaria de agradecer pela oportunidade de fazer este registro. Eu acho importante que a memória da história de vida de quem vem da favela seja levada em conta. Porque a gente tem um processo de apagamento histórico ou de homogeneização da nossa existência. Então, quando a gente está contando nossa história, a gente está ressignificando nossa existência como indivíduo. É tão difícil falar como foi, porque, óbvio, nada é por acaso. Às vezes parece que foi obra do acaso, mas não é.

\section{A vida na favela e o início da militância comunitária}

Nasci na favela do Borel, onde me criei, criei meus filhos, me casei. Tenho dois filhos e um neto de 2 anos. Vivi lá por 48 anos. Há alguns anos estou morando no centro, saí do Borel. Minha trajetória é marcada pela falta e pela ausência parcial do poder público, pois olhando para a segurança pública, a presença das forças policiais na favela é uma constante. Isso não mudou 
muito, mas em relação às outras políticas, foram sempre permeadas pela ausência, pela falta: de água, de sensibilidade, de moradia adequada etc.

Posso marcar minha entrada na militância em 1988, numa perspectiva mais elaborada do que a gente entende como militância comunitária; a partir das chuvas de $1988,{ }^{1}$ das tragédias que acometeram a cidade do Rio de Janeiro e suas favelas. Naquele momento, eu me entendi como alguém do coletivo, ainda sem elaborar muito, mas entendendo que eu tinha que estar de alguma maneira ajudando, me envolvendo. Para além de ser alguém que vive na favela, que sai de manhã para trabalhar e volta de noite. Porque naquele momento não bastava só observar o que estava acontecendo e não incidir de algum modo. Aquele momento foi um marco de início na militância comunitária, de atuação na favela. Tenho muito orgulho de dizer que minha construção nessa caminhada - igreja, academia, Parlamento - está muito encadeada por todas as lutas junto com o trabalho e a ação de sobrevivência. Naquela militância coletiva, comecei a compreender a favela, a olhar a favela de modo mais amplo, para além do local onde eu morava. Meu mundo se resumia à Ladeira do Moreira. Com a tragédia de I988, comecei a conhecer o morro do Borel. Porque sou do tempo que morro era morro e favela era favela. Então, estou usando o termo morro. Não sei se Itamar...

IS: É igual ao Morro Santa Marta.

MF: Quem estava na favela plana, era favela. Então, eram os moradores do morro e os favelados, a gente tinha essas duas categorias. Hoje, tudo é favela. Havia uma brincadeira que a Ladeira do Moreira era a "zona sul" do Borel. Quer dizer que não fazia parte do Borel, mas da Candelária. Nesse momento, eu passo a descobrir o morro, as pessoas de outras áreas, principalmente das áreas mais atingidas, porque morreu muita gente nas favelas, praticamente do Rio de Janeiro inteiro.

IS: Perdi minha avó em I988; a casa veio abaixo, completamente.

MF: No Borel, parte do morro veio abaixo, também. Posso dizer que ali nasceu a Mônica que conhece o morro, e a partir dali não parei mais: trabalho, militância, igreja.

\section{A conversão para a igreja evangélica}

MF: Eu me converti em dezembro de 1988, quando comecei a frequentar a igreja evangélica. Até então eu me reivindicava católica, não era praticante. Eu ia à missa de vez

\footnotetext{
${ }^{1}$ Enchente e deslizamento no Rio de Janeiro com 289 mortos, 734 feridos, 18.560 desabrigados. Ver: <https://agenciauva.net/2019/04/09/enchentes-fazem-parte-da-historia-do-rio-de-janeiro/>.
} 
em quando. Minha família se dizia católica porque era mais cômodo, mas parte dela era ligada à religião de matriz africana.

A primeira igreja com que eu tive contato foi a Igreja Universal do Reino de Deus, e ali, no Borel, eu organizava a igreja, dirigia o núcleo da igreja. Depois eu fui para o Instituto Bíblico Universal do Reino de Deus (IBURD). Saí da Universal em I995/1996 e fui visitar a Igreja Batista, no Borel mesmo, e lá fiquei até 20I2. Posso dizer que sou mais Batista do que o tempo que fiquei na Universal. Sou evangélica há 32 anos, fui consagrada pastora em 20I2, é muito recente. Acho ótimo também para desconstruir um pouco essa figura do que é o pastorado. Isso era uma coisa íntima, não se falava disso até a campanha.

\section{Primeiros trabalhos e a aproximação com a Associação de Moradores do Borel}

Cheguei à Associação de Moradores do Borel para disputar uma vaga de secretária, que não consegui, pois nem tinha feito curso de datilografia. Mas o filho do presidente da associação, que também atuava lá, perguntou se eu queria ajudar no alto-falante, para montar uma rádio. Eu não conhecia nada de rádio, mas me envolvi assim mesmo, só que não tinha salário, tinha que conseguir patrocínio. Nesse meio-tempo, fui trabalhando em tudo que conseguia: aos I4 anos, como operária em uma fábrica de tecidos no polo industrial na Tijuca, onde existiam várias indústrias, ali foi meu primeiro emprego de carteira assinada, em I984; já distribuí panfleto, trabalhei em firma de limpeza, passando por vender seguro e em supermercado. Entre vários empregos precários, continuava ligada à igreja, e sempre com um "pezinho" na atuação comunitária. Por causa da relação com a Associação de Moradores do Borel, atuei na chegada do programa Saúde da Família, fazendo toda a divulgação; ajudei na chegada do Posto de Orientação Urbanística e Social (POUSO). Inicialmente, o POUSO tinha o papel de orientar os moradores para as obras, para as realocações, enfim fazer toda aquela orientação das equipes de educadoras, de agentes comunitários. Depois, passei a ser agente comunitária de habitação, passei pela Secretaria de Urbanismo e pela CEDAE. Trabalhei em praticamente todos os programas de urbanização e reurbanização. E só há pouquíssimo tempo fui me dar conta disto: trabalhei nos programas Favela-Bairro, Morar Carioca, PAC das Favelas e Água para Todos.

Nisso tudo, a gente sai da nossa favela e vai para outras favelas. Até 2003, posso dizer que minha militância era muito ligada à questão das políticas de habitação e saúde. Acho que as atuações vão se suplantando, se juntando e criando uma dinâmica que vai formando nossa identidade, nos contornando como indivíduos, indivíduos em sociedade, para além da favela ou do morro, no nosso caso, Itamar, para além do morro. Então, eu me vi como uma mulher negra e favelada que era agente comunitária, que tem essa trajetória de todos os trabalhos imagináveis. Até 2003, atuei na luta das mulheres, mas com uma pauta do trabalho, da inserção das mulheres, da habitação, da água. A luta pela água sempre foi uma questão. 
A questão da violência policial, da segurança pública... Atravessava tudo isso, obviamente, e a própria violência do varejo da droga. Porque é o cotidiano, é a vida, a militância tem de discutir isso, os impactos disso nas ações que a gente vai fazer e não consegue, pois é interrompida. Mas até ali não era uma questão sobre a qual a gente se debruçava, especificamente, estávamos organizando a associação de mulheres.

\section{Chacina do Borel}

No ano de 2003 inauguro minha militância com esse viés de enfrentamento da violência policial letal. Porque foi o extremo quando aconteceu a chacina do Borel, em $2003 .{ }^{2}$

A gente já enfrentava este debate na articulação com as mulheres. Estava tudo muito atrelado: atuação como agente, articulação com a Agenda Social Rio, ${ }^{3}$ as discussões ali da Grande Tijuca, do próprio Programa Favela-Bairro, ${ }^{4}$ o impacto naquele período com aquela movimentação na Grande Tijuca. E, depois, a ampliação com a articulação com o Instituto Brasileiro de Análises Sociais e Econômicas (Ibase) ${ }^{5}$ e com outras ONGs. Enfim, foi se criando a necessidade de mais organização para o enfrentamento da violência letal por parte das polícias, da política de segurança pública destinada às favelas. Essas articulações aconteciam em um período em que não tínhamos nem celular nem internet. Tudo acontecia sem nenhum recurso tecnológico para além do telefone, que também não era para todo mundo. Conseguimos nos articular por essas outras relações. Nesse sentido, acho que o papel das redes foi fundamental. Se a gente trouxer para o que está acontecendo agora - por conta dessa crise sanitária da pandemia -, podemos ver o quanto as redes sociais anteriores ajudaram e seguem ajudando na construção de novas redes e consolidações que estão na vida cotidiana dos favelados e faveladas, dos periféricos e periféricas.

Essa articulação anterior ajuda a mobilização para enfrentar a violência letal da polícia, pois a gente já estava nessa articulação com as mulheres. A partir daí a gente vai mobilizar a favela.

\footnotetext{
2 “Em 16 de abril de 2003, quatro jovens foram executados à queima roupa por policiais do $6^{\circ}$ Batalhão da Polícia Militar na favela do Borel, zona norte do Rio de Janeiro. Os policiais alegaram legítima defesa e o caso foi registrado inicialmente como 'auto de resistência'. Testemunhas, familiares das vítimas, e evidências forenses indicavam que se tratavam de execuções extrajudiciais. As investigações concluíram que os quatro jovens foram executados, que os policiais não agiram em legítima defesa e identificou os policiais responsáveis. No entanto, quinze anos depois, ninguém foi responsabilizado. A chacina do Borel ganhou repercussão internacional. Em 2003, a relatora especial da ONU para Execuções Sumárias, Arbitrárias e Extrajudiciais, Asma Jahangir, esteve na favela para ouvir os relatos dos parentes das vítimas e incluiu o caso no seu relatório sobre sua missão ao Brasil. Ainda no ano de 2003 , a secretária-geral da Anistia Internacional, Irene Khan, também visitou o Borel para conversar com os parentes das vítimas”. Disponível em: <https://wikifavelas.com.br/index.php?title=Chacina_do_Borel>. Acesso em: 14 nov. 2021.

${ }^{3}$ Ver: <https://ibase.dev.eopen.com.br/portfolio/agenda-social/>.

${ }^{4}$ Ver: <https://wikifavelas.com.br/index.php?title=Programa_Favela-Bairro_-_1\%C2\%AA_fase>.

${ }^{5}$ Ver: <https://ibase.br/>.
} 
É uma tarefa muito árdua porque no evento da chacina do Borel, que vitimou quatro jovens na semana anterior, tinha acontecido um confronto e uma revolta da comunidade. Já havia uma desconfiança da própria comunidade, já estavam chamando a gente para descer. As mulheres estavam organizando, e começaram a ouvir uma série de depoimentos de violações da polícia com mulheres que chegavam tarde do trabalho, que vinham sozinhas, que eram abordadas, mas pedindo pelo amor de Deus para não falar. Vejam como é o pavor e o medo! A pessoa imagina que no dia seguinte poderia ter um policial na porta dela, porque ela falou que a filha estava chegando do trabalho, ou de outro local qualquer, e foi molestada pelo policial; ou foi alvo de constrangimento, ou xingada, e tudo mais que a gente sabe.

Ali foi o marco, porque a gente consegue não só mobilizar o Borel, mas consegue a adesão de outras favelas. Lembro que Itamar estava lá. A gente conseguiu mobilizar uma série de favelas e fez uma caminhada silenciosa até a Praça Saenz Peña, a principal praça do bairro da Tijuca, zona norte do Rio de Janeiro. Essa caminhada marcou também uma organização posterior que reverbera até hoje. Antes de 2003, havia uma organização das mães dos II desaparecidos de Acari. ${ }^{6}$ O Movimento Posso me Identificar ${ }^{7}$ foi muito importante, uma mobilização ${ }^{8}$ após a chacina do Borel que em seguida foi ampliada, veio o MST em outras passeatas, mas nessa inicial eram as pessoas das favelas, majoritariamente.

IS: Mônica, nesse momento, seu protagonismo era claríssimo. Estava explícito, principalmente nessa mobilização dentro do Borel. Como você disse, já vinha de um trabalho com as mulheres e segue até hoje, como um desdobramento, trouxe outros movimentos, mas ali tinha uma expressão muito forte das favelas. Eu queria que você explorasse um pouco mais esse associativismo a partir do Borel. Você saiu da "Ladeira" para ver o morro do Borel, mas eu acho que teve o movimento que foi sair da "Ladeira" para ver as favelas, para ver o conjunto de favelas daquela região da Tijuca que também vai junto com sua formação, que vai se consolidando. $O$ que você acha?

MF: Poderia dizer que somos isso tudo, multifacetados, nessa síntese que você está fazendo. Mas em relação às outras favelas do complexo do Borel e da Formiga, eu conseguia circular nesses espaços, acho que uma coisa foi legitimando a outra. Ainda não tinha essa coisa de "porque é evangélico". Conta o fato de eu ser mulher e tentar achar uma resposta para essa

\footnotetext{
${ }^{6}$ Ver: <https://almapreta.com/sessao/quilombo/maes-de-acari-30-anos-de-uma-luta-coletiva>.

${ }^{7}$ Ver: <http://www.alerj.rj.gov.br/Deputados/PerfilDeputado/438?Legislatura=19>.

8 "A primeira mobilização recebeu o nome de "Posso Me Identificar". Foi uma chacina na qual foram assassinados cinco jovens que não tiveram nem condições de se identificar. [Os policiais] taxaram no peito destes homens que eles eram bandidos, que eles eram traficantes e os mataram. E não eram. Eram só jovens, moradores do Borel que foram assassinados por policiais. Todas essas pessoas, familiares e amigos de vítimas de chacina, se sentiram sensibilizadas e revoltadas por estarem morrendo, a toda hora, pessoas nas suas favelas e resolveram se juntar”. Disponível em: <https://rioonwatch.org.br/?p=18634>. Acesso em: 9 mar. 2016.
} 
legitimidade. Mas como bons conhecedores de morro e favela que nós somos, sabemos que o currículo nos precede. Podemos achar que não, mas todo mundo acaba nos conhecendo e conseguimos articular com todas as favelas. Acho que obtivemos um protagonismo importante no Movimento Posso me Identificar que se desdobrou do Borel e tomou uma proporção enorme. A partir da perspectiva de que essa mobilização ajuda a consolidar e talvez organizar melhor a luta das mães, e eu acho que, inclusive, a própria política pública nacional, como o Programa Nacional de Segurança Pública com Cidadania (Pronasci), fomos vendo os desdobramentos, e o Posso me Identificar acabou se ampliando para uma luta por moradia nas ocupações (a luta das mães com a ocupação Chiquinha Gonzaga, mais recentemente Manuel Congo). Chiquinha Gonzaga era a grande ocupação na época, na zona portuária, reunindo e fortalecendo a luta das mães. Então, nasceu a Rede de Comunidades e Movimentos contra a Violência, que hoje virou Rede de Mães Contra a Violência do Estado. ${ }^{9}$ Dalva do Borel está como a grande mãe, vamos dizer assim, a grande figura, e tem esse desdobramento lindo, que vai dando sentido para a luta das mães que estão protagonizando tudo isso. Ali, de fato, é um marco de uma luta depois do grande movimento pela manutenção e permanência das favelas contra a remoção. Posso me Identificar foi, de fato, uma luta dos favelados. Hoje, a gente diria que foi o "nós por nós" ${ }^{10}$ na veia, raiz. Lembro-me de Itamar e de outros companheiros e companheiras falando no carro de som, a gente andando e o povo do Tijuca Tênis Clube correndo e se escondendo, porque a gente representava também o fantasma dos arrastões. ${ }^{11}$

IS: Insisti nesse ponto porque acho que ele marca, não só para nós, mas marca a história do enfrentamento da violência policial no Rio de Janeiro. Marca do ponto de vista da organização que vai em direção à costura com outros movimentos, com outras instituições. A mesma tensão dentro do Posso me Identificar, que vai se desdobrar na "Rede". Ele é importante na perspectiva de uma articulação e de uma múltipla temática. Ele deixa de ser só uma questão de enfrentamento com a polícia e passa a ser um movimento que enfrenta, talvez, todas as necessidades de todas as violências contra as favelas e contra os pobres. Por isso que eu insisti um pouco nesse ponto, porque eu acho que é importante marcar sua trajetória, sua primazia nesse movimento. Ele foi fundamental não só na sua formação, mas na perspectiva de luta do movimento de mulheres e movimentos de favelas aqui, no Rio de Janeiro.

MF: Exato. Nesse ponto, a gente articula com outras ações, outros movimentos, como o movimento de economia solidária que vamos conhecer depois, e o movimento de rádios, que já tinha uma relação, no passado, com a Associação de Moradores do Borel. No âmbito da Agenda

\footnotetext{
${ }^{9}$ Ver: <https://rioonwatch.org.br/?p=18634>.

${ }^{10}$ Ver: <https://www.geledes.org.br/o-significado-do-nos-por-nos/>.

${ }^{11}$ Ver: <http://www.portcom.intercom.org.br/pdfs/154683808182665503562608596922515010637.pdf>.
} 
Social, a gente construiu a Rádio Grande Tijuca em articulação como uma escola privada, uma ONG, o Ibase, a sociedade civil organizada, mas também como um espaço de encontro no auge da chamada guerra do tráfico na Grande Tijuca. Foi a possibilidade do encontro desses atores e atrizes, favelados e faveladas, com o asfalto. No momento que a gente estava discutindo a cidade, estava discutindo favela e asfalto. Lembro que em 2003/2004 aconteceu aquele seminário que organizamos com a Márcia Leite, da Universidade do Estado do Rio de Janeiro (UERJ), com a presença de várias outras professoras das universidades, no Country Club da Tijuca, para discutir a cidade, a questão urbana, e depois teve aquele seminário enorme na Caixa Econômica; um ambiente ajudando a ampliar esse entendimento do ativismo, da militância, da relação com a intelectualidade, essa provocação dos intelectuais orgânicos, por exemplo, por parte do Luiz Antonio Machado da Silva. Em paralelo, eu estava fazendo pré-vestibular comunitário na Igreja Nossa Senhora da Conceição para entrar na universidade.

\section{Ingresso na universidade}

IS: Essa motivação para entrar na faculdade era uma necessidade de ampliar autoridade no diálogo com esse mundo acadêmico que já estava circulando em torno dos movimentos? Qual foi a motivação?

MF: Era um desejo antigo. Na verdade, eu queria fazer história, talvez eu ainda faça. Cursar Ciências Sociais significou, obviamente, tentar compreender esta sociedade desafiadora. A influência dos amigos acadêmicos ajuda também, mas já era um desejo antigo, e o prévestibular apareceu. Era um pré-vestibular muito bom na Igreja Nossa Senhora da Conceição, mas que infelizmente acabou por uma pressão da classe média tijucana. Acho que isso também ajudou no processo de querer ir para a universidade e cursar Ciências Sociais. Toda aquela articulação naquele momento juntou com essa vontade, com esse desejo. Então, começou minha história acadêmica, em 2008.

IS: Sobre seu mandato, o país está em outro contexto. Um contexto que tensiona toda a trajetória do passado, mas que está resistindo e que permitiu, por exemplo, uma eleição que elegeu no mínimo três mulheres negras na Alerj: você, Renata Souza e Dani Monteiro. Em parte, tem o efeito Marielle, mas eu queria que você explicasse um pouco essa questão sobre os desafios do mandato coletivo. São mandatos populares de mulheres que vêm da favela e que carregam uma tradição, carregam uma história muito específica, mas que não é só de vocês, é desse contexto da favela e da militância, dessa história que você nos relatou. Quais são as questões que você gostaria de destacar como elementos estratégicos, desde a aprovação de projetos à disputa interna. Você poderia explorar um pouco essa nova conjuntura? 
MF: Sem dúvida, eu acho que a própria eleição da Marielle foi uma composição de conjuntura que vinha muito na esteira da Primavera das Mulheres, do Fora Cunha. Isso ajudou muito, foi uma janela aberta à reafirmação da luta das mulheres, por exemplo, com a Marcha das Mulheres Negras, ampliando no Rio de Janeiro, e que ajudou a fortalecer e a garantir a eleição de Marielle. Certamente, tem toda a trajetória dela, a própria articulação na Comissão de Direitos Humanos; mas não só, acho que foi muito ancorada nessa luta das mulheres que estava efervescente em 2015 , principalmente com o que aconteceu com a Dilma. O próprio golpe teve uma resposta por parte do coletivo de mulheres e que, obviamente, Marielle, trazia para dentro da Câmara de Vereadores; e eu me inspiro nesse coletivo. Acho que fui a última pessoa que ela convidou para compor a mandata. Não aceitei de pronto, primeiro porque nunca tinha trabalhado em mandato parlamentar, tinha muitas ressalvas em relação a isso. Por conta de tudo que se sabe da relação da favela com o campo político, muito fisiológico, mesmo admirando os companheiros que estão nessa trajetória, estar dentro de um mandato não estava no meu horizonte. Muito pelo contrário, naquele momento, no final de 20I6, queria continuar no Laboratório Territorial de Manguinhos (LTM), ligado à Fiocruz. Na época, eu escrevia para o Jornal do Brasil, na coluna Comunidade em Pauta. Finalmente eu aceitei, pois era a companheira Marielle. Comecei como assessora na equipe de favelas. Acho que retomo aqui minha fala inicial, pois na vida as coisas vão se juntando e criando também uma conjuntura muito específica.

Depois, Marielle foi descobrindo que minha atuação não era apenas no Borel - como ela me conheceu. Ainda descobriu que eu sou pastora, e começou a falar que eu precisava me candidatar para 2020. Marielle estava refletindo sobre a construção de um mandato para ocupar a herança de Benedita e de Jurema, ambas mulheres negras, com hiatos de tempo enormes entre as duas eleições e em relação ao mandato dela, que começou em 20I7. Para que não mais acontecesse esse hiato - fazia I5 anos que Jurema havia saído da vereança -, Marielle considerou que era uma oportunidade eu disputar no campo religioso e no campo da economia solidária. Mas aconteceu aquela tragédia com a execução de Marielle e Anderson, em I4 de março de 20I8...

\section{Lançamento da campanha na $\mathrm{ABI}$}

IS: Mônica, aquela ação da sua campanha na Associação Brasileira de Imprensa (ABI), eu estava lá. Ficou muito explícita a diversidade da sua campanha, que ali tinha uma representatividade muito forte. Na verdade, eu sempre desconfiei muito de campanha, acho muito difícil campanha de favela. A gente sempre enfrenta essas dificuldades que você já mencionou. Quando saí dali, encontrei gente que também comentou isso, que naquele momento, naquela reunião, naquele ato, ficou muito evidente a força da sua campanha para 
além do próprio PSOL; só não imaginava tantos votos como você teve. Imagino que com Marielle tenha acontecido mais ou menos o mesmo.

MF: A ABI foi isso. Houve muita dificuldade para conseguir aquele espaço; a gente batalhou para todo mundo comparecer, o povão. Porque era outra coisa que me diziam, que favela não dá voto. Mas como eu não vou falar com a favela? Não existe, na minha vida, essa possibilidade!

Como no Borel todo mundo me conhece, então praticamente não fiz campanha no Borel, fui para outros lugares, tinha de ir onde não era conhecida. E para minha surpresa fui votada pela metade dos eleitores do Borel; não sei como isso aconteceu. Tenho algumas hipóteses: talvez o trabalho já realizado, a legitimidade que conquistei, minha relação com as pessoas, acho que tudo se traduziu nos votos que eu recebi. Então, depois de muitas conversas e com muitos receios, estou aqui na disputa, começando pelo uso do termo mandata.

\section{Desafios da mandata quilombo para uma mulher negra e favelada}

Essa ocupação é extremamente revolucionária: a disputa ocorre dentro da Alerj, que é o centro da política do estado do Rio de Janeiro, numa configuração completamente adversa, com a presença de uma extrema direita que se reorganiza com base na pauta da "escola sem partido".

Os avanços que a gente consegue dentro do Parlamento, eu digo, sem medo de errar, com a minha condição de mulher favelada, é com a experiência dessa caminhada que me proporciona a capacidade de articular dentro dessa nova arena de luta. Porque não dá mais para fazer política sem a gente e, pensando muito na Marielle, há algum tempo nós dizemos que não dá para discutir a cidade sem a favela.

A gente consegue radicalizar nas intervenções, é o "papo reto", essa dinâmica que vem da favela e da periferia, onde temos de conviver com todo mundo. Porque uma coisa é você viver na favela, outra coisa é militar na favela. Eu consegui trabalhar no Borel. Sair da favela foi um processo lento, porque eu digo e repito: ser favelado não é só morar na favela, é uma relação muito forte e uma construção subjetiva fortíssima.

Mas a gente não tinha muita certeza de como construir uma mandata quilombo. Mandata no sentido de ocupação de mulheres com avanços na luta da população negra no Brasil, apesar dos enormes desafios. Historicamente, o quilombo, além de ser formado por pessoas negras fugitivas, ou de ex-escravizados, tinha uma organização muito singular e uma articulação com o Estado vigente, com regras e engrenagens próprias. Então, a mandata quilombo não é uma nova política. Falo isso, generalizando e até tomando essa liberdade, porque nossa forma de fazer política vem muito contaminada dessas trajetórias. Desde a linguagem até a forma de articulação, embora as origens sejam as mesmas - Renata Souza, Dani Monteiro e eu, três mulheres negras e nascidas em favela -, essa origem de construção de identidade de luta e de formas de atuação são necessariamente marcadas pelos caminhos que a gente vai trazendo. 
Costumo dizer que a minha forma de fazer política é contaminada pela minha essência favelada e pelo papo reto. O que é essência favelada? Quem é de favela sabe, você vai ter que lidar e buscar conviver com todo mundo de uma maneira minimamente harmônica, porque isso implica sua sobrevivência, a sobrevivência da sua família, a manutenção da sua moradia, a sua possibilidade de circulação. A gente fez uma pesquisa sobre o que legitima a liderança de favela, e creio que é essa dinâmica, pois na favela todo mundo sabe quem você é, quais os passos que você dá, então isso vai legitimando você - ou não. Acredito que eu consegui chegar ao Parlamento - e o número de votos me surpreendeu também -, como resultado dessa dinâmica, em que o peso da execução da Marielle é inegável, mas teve também o processo de legitimidade ao longo da minha trajetória.

Chegamos a esse lugar de mandato parlamentar, com todas essas engrenagens da máquina institucional, que impossibilitam muita coisa, mas vamos conseguindo transpor as dificuldades. Com o PSOL, a gente conversava com a zona sul, com a universidade, que também é nosso espaço; com as centrais sindicais, com os sindicalistas; a gente conversava com todo mundo, mas ficava um incômodo de certa incapacidade de enxergar a favela, essa favela de que a gente é parte.

Eu digo que está nessa mandata quilombo disputar a palavra mandata para significar a presença nesse lugar de mulher, feminista preta, que atua dessa maneira, e a gente consegue se legitimar no Parlamento desse jeito. No início, foi bem complicado, não tínhamos um referencial, pois quem deveria ser nosso referencial foi assassinada. Então acho que a nossa mandata tem essa característica de ser contaminada pela trajetória e pela essência favelada no seu dia a dia.

IS: Quando você também milita na favela, você sai da favela, mas a favela não sai de você.

MF: Exato, e eu ainda tenho muita dificuldade. Se está acontecendo operação policial na favela, eu vou pegar o telefone e ligar para o governador; para isso serve a parlamentar. Mas é uma permanente disputa que a gente tem que fazer, é um processo pedagógico da favela. Como pessoas como nós, que ocupamos cargo político, atuamos nessa mandata?

Eu diria que estamos trazendo novos elementos com a chegada de corpos insurgentes, periféricos. A margem ganhou um protagonismo no centro da cena política. Criamos novas maneiras de fazer política. Acho que trazemos a forma de atuação do processo de militância nas nossas áreas, dessa legitimidade que a gente tem dentro da sociedade, da favela, da periferia, da militância no movimento social, no coletivo, na maneira de lidar com todo mundo. Isso a gente traz porque está introjetado em nossa forma de fazer política, que não era institucional. Mas ela se institucionaliza também. E aí existem dois riscos: o risco para o sistema, pois a gente pode conseguir fraturar o sistema em algum momento e ruir com tudo isso; e o outro risco, que é o de ser absorvido pelo sistema.

Pode-se usar o termo nova forma ou forma alternativa ou outro nome que podemos dar para essa "gambiarra". Conseguimos avançar porque a gente pauta a favela em outra lógica, e traz 
parte da favela; porque a gente não traz toda a favela, tem uma parte que está dentro da lógica fisiológica mesmo.

Como lidar com uma candidatura coletiva? O que é isso? O que são dez pessoas dividindo o mandato, mas apenas uma podendo se sentar na Tribuna? Não existe uma mandata coletiva, por exemplo, nos regimentos internos das casas legislativas. Como eu lido com a militante, uma mulher negra que tem sororidade? Como trabalhar? Os desafios são enormes. Tentando legislativamente atuar, seja com emendas ao orçamento, mas também atuando no território. Nesse momento, vem a desconfiança se essa atuação teria como motivação ganhar voto na próxima eleição. Outro grande desafio é o de experimentar novas formas de racismo que a gente ainda não sabe dar nome. Nesses dois anos como deputada, venho lendo as reflexões de Lélia Gonzalez sobre suas angústias. Estou lendo Judith Butler, que ajuda a entender essa existência em tragédia do povo negro em diáspora, que nos persegue em todos os sentidos. É um sofrimento com o qual a gente vai aprendendo, e nos persegue até hoje na sociedade. Obviamente que várias pessoas falaram sobre isso, além da Lélia Gonzalez, Neusa Santos Souza, Grada Kilomba e Abdias do Nascimento, que tratou do genocídio do povo negro. A gente está falando sobre isso e o Emicida está cantando isso. Nossa turma de mandato está pesquisando, a gente está produzindo material sobre isso, mas eu sinto que ainda falta. Eu acho que a gente vai ampliar essa dinâmica, como é o caso do próprio Ivanir dos Santos falando das religiões de matriz africana. Trata-se de produzir uma reflexão sobre esse sofrimento, essa existência em tragédia, que é claro que a gente ressignifica com uma beleza tremenda.

IS: O Abdias do Nascimento virou uma referência na construção do que a gente está vivendo hoje, é a mesma coisa quando vemos a Maria Carolina de Jesus e o reconhecimento dela como doutora honoris causa, ${ }^{12}$ e sendo recuperada como referência por todas as mulheres nas academias. Negros intelectuais e escritores agora estão sendo incorporados na dimensão de instrumentos de reflexão, de apontar caminhos, veja a importância do Kabengele Munanga, ${ }^{13}$ que escreveu sobre a questão das cotas raciais e esteve presente na formação, por exemplo, de Silvio Almeida. Para mim, o mais eloquente e forte neste momento são essas conexões, o caso da Djamila Ribeiro que faz esse trabalho, isso é fundamental nesse processo.

MF: E tudo isso ajuda dentro de um mandato parlamentar. Por exemplo, ter a bandeira de luta antirracista como uma luta constante, produzir uma legislação que vai destinar emendas para ajudar as vítimas de violência do Estado, destinar dinheiro do fundo público de combate à pobreza e da Segurança Pública, porque esse fundo não pode ser usado pelo Estado como vem sendo usado... Óbvio que temos aliados, temos articulação, mas apresentamos aqueles pontos

\footnotetext{
${ }^{12}$ Ver: <https://www.geledes.org.br/carolina-maria-de-jesus-ganha-titulo-de-doutora-honoris-causa-da-ufrj/> .

${ }^{13}$ Ver: <https://www.scielo.br/j/ea/a/MnRkNKRH7Vb8HKWTVtNBFDp/?lang=pt\&format=pdf>.
} 
como pauta central, e o Parlamento tem que ouvir, tem que discutir, creio que esse é o nosso diferencial. Mas primeiro você prepara esse ambiente e legitima sua presença, pois está tudo ali presente: violências, desqualificação, não reconhecimento. Está presente a existência em tragédia de que estou falando, em que você está ali, mas é aquele elemento da sociedade que é desumanizado integralmente, todo o tempo. É impressionante ouvir determinadas intervenções, inacreditável... Você é uma mulher negra e alguém se dirige a você assim, não porque foi eleita, mas porque é do Borel, favela do Comando Vermelho - suspeita sobre a "coincidência" de você ser eleita e acusar a polícia, sendo do Borel. O fato de termos o presidente da Alerj de um partido de esquerda, no caso do PT, ajuda o sancionamento de alguns projetos, mas estou com vários projetos vetados, lutando para derrubar o veto no colégio de líderes.

\section{O trabalho nas comissões da Alerj}

IS: Poderia expor um pouco sobre os espaços que você foi conquistando na estrutura da própria Assembleia? E o significado dessas comissões?

MF: Foi um espaço de disputa muito tenso, primeiro na própria bancada, porque ninguém me conhecia. Foi um processo exponencialmente mais violento, porque você está atravessado por um trauma absurdo. Essa vitória eleitoral foi uma vitória realmente coletiva; as pessoas lutaram e trabalharam muito para isso acontecer. Então, a gente chega no Parlamento com muita desconfiança. Eu só queria a Comissão de Combate às Discriminações e Preconceitos de Raça, Cor, Etnia, Religião e Procedência Nacional, a vice-presidência já daria para a gente organizar.

Em seguida, fomos tentando ajustar nossa política ao que "sobrava", ao que ninguém queria. Então, o que nenhuma bancada queria, a gente pegava. Inicialmente, a gente não teria nada, porque ninguém vai brigar pela gente. Havia uma comissão do trabalho, e ninguém queria; então pegamos a de trabalho. Foi uma hecatombe na equipe, sobretudo porque acabamos ficando com a presidência!

Para acalmar a equipe da mandata, logo informei que iríamos trabalhar do nosso jeito. Ninguém nos havia informado que teríamos direito a cargos. E começamos, então, a montar a equipe, hoje com 33 pessoas. Na comissão do trabalho, diante do quadro de precarização da classe trabalhadora, começamos a fazer articulação com mulheres empreendedoras, pessoas que estão na favela, nos aplicativos de transporte, é com essa galera. Vamos interseccionalizar; o trabalho e a seguridade social passam a ser nosso eixo central de luta. Quem depende de seguridade? Preto, pobre, favelado? Vamos lá, vamos costurar. E a gente foi construindo essa dinâmica. Tropeçamos muito; foi tentativa e erro para consolidarmos o trabalho.

No final de 2020, lançamos um relatório, que nem ficou do jeito que eu queria, poderia ter sido melhor, mas foi o que pudemos fazer, e o impacto foi enorme, deu a maior repercussão. Fui, 
então, reconduzida à presidência da comissão do trabalho, ${ }^{14} \mathrm{e}$ foi muito legal receber de alguns parlamentares ligações dizendo o quanto conseguimos imprimir uma marca, ver que conseguimos ter o respeito deles, enxergar nossa capacidade de mediação... Isso vem da essência favelada que eu falei, foi se consolidando, até chegou um convite de um deputado que vai criar uma frente... Na comissão do trabalho tem uma socióloga e um sociólogo, uma profissional do serviço social, uma economista, um geógrafo, todos são coordenadores. Agora a gente está começando o observatório do trabalho popular, já com um primeiro levantamento publicado em jornal do Rio.

\section{Participação na aprovação do tombamento do Terreiro de Joãozinho da Gomeia ${ }^{15}$}

Mas a gente tem algumas vitórias. Mais uma vez atribuo a capacidade de aprovar projetos importantes a essa legitimidade que conquistamos na Alerj, como foi o caso do Joãozinho da Gomeia, sobre combate ao racismo religioso, em 27 de março de 2020. A luta pelo tombamento do Terreiro do Joãozinho da Gomeia foi uma guerra, literalmente, contra o clã Malafaia e contra o clã Washington Reis, de Caxias. Eu me senti super-honrada de poder ter sido uma ferramenta para concretizar a luta coletiva dos herdeiros espirituais do Joãozinho da Gomeia. Eu me surpreendo, porque o Samuel Malafaia tinha colocado, sei lá, milhares de emendas para descaracterizar o projeto, para destruir o projeto. Por fim, tiravam o nome de Joãozinho da Gomeia, porque 27 de março é o dia do aniversário dele. Foram duas vitórias que vieram de uma luta popular muito legítima: o dia 27 de março, que marca uma série de ações contra o racismo religioso; e o tombamento do terreiro histórico. As forças que estavam em torno da disputa pelo terreiro eram muito fortes: da especulação imobiliária até a milícia. Havia uma articulação de poder político, miliciano e financeiro naqueles espaços da Baixada Fluminense e em Caxias, especificamente, que estavam mirando aquele terreno. Foram forças muito grandes, muito poderosas.

\footnotetext{
${ }^{14}$ A Comissão de Trabalho, Legislação Social e Seguridade Social da Alerj foi instalada em 06 de abril de 2020. A deputada Mônica Francisco (PSOL) foi reeleita presidente, e a deputada Enfermeira Rejane (PCdoB) ficou com o cargo de vice-presidente.

15 “Aprovado o Projeto de Lei 2905/20, de autoria da deputada Mônica Francisco (Psol), que determina o tombamento por interesse histórico e cultural da área do Terreiro de Joãozinho da Goméia, localizada no município de Duque de Caxias. A proposição foi criada no período em que havia um movimento pela conservação do terreno, considerado sagrado pelos praticantes de religiões de matriz africana, uma vez que Prefeitura de forma unilateral decidiu descaracterizar o local para fazer uma construção. Para a parlamentar, que é vicepresidente da Comissão de Combate às Discriminações e Preconceitos de Raça, Cor, Etnia, Religião e Procedência Nacional, é perfeitamente possivel aliar o desenvolvimento com o patrimônio histórico-cultural das cidades. E quando se trata de espaços que fazem referência às religiões de matriz africana, em regiões em que são frequentes os ataques racistas a estes marcos, o cuidado deve ser ampliado". Disponível em: <https://monicafrancisco.com.br/tombamento-do-terreiro-de-joaozinho-da-gomeia-pode-ser-garantido-porlei/>. Acesso em: 04 jul. 2021. Ver também: <https://www.brasildefatorj.com.br/2021/04/30/dia-joaozinho-da-gomeia-se-torna-lei-eterreiro-e-tombado-em-caxias-rj>. Acesso em: 13 nov. 2021.
} 


\section{Sobre a Covid-19 na favela e a Alerj}

Acho que a gente conseguiu um protagonismo importante na comissão de saúde. É claro que foi uma dobradinha com nosso assessor, que é enfermeiro, e era muito importante ir com ele nas reuniões da comissão, legitimar nossa atuação na comissão de saúde. Mas explodiu a pandemia, e criou-se a Comissão Especial Covid. Foi um trabalho hercúleo. Eu já vinha acompanhando a questão de uma das $\mathrm{OS}^{16}$ por conta do Hospital Getúlio Vargas. Estava acompanhando os terceirizados e as mulheres grávidas que eles, por fim, tinham colocado no limbo, uma situação complicada com as OS. Enfim, conseguimos criar o Dia Estadual de Mobilização para Enfrentamento da COVID-I9 nas Favelas do Rio de Janeiro ${ }^{17}$ e a legitimidade dentro da comissão de saúde. Ainda tenho muito a aprender, mas é inegável que a gente conseguiu se legitimar dentro da Alerj.

Voltando ao tema da minha candidatura e a relação do mandato com a favela, foi realmente um grande desafio. Comecei aqui falando dessa resistência porque a relação sempre foi de muito fisiologismo. E agora eu sou a política com mandato parlamentar, as desconfianças estão colocadas, porque são históricas. Elas estavam em mim, elas estão na favela e na periferia em geral. Mas em relação ao Borel, a gente vem conseguindo construir uma série de ações que têm sido muito interessantes. Para mim, tem essa enorme dificuldade de desatrelar a militante favelada de grande parte das minhas ações. Acaba sendo muito mais a militante usando as ferramentas parlamentares do que uma parlamentar. Então, é por isso que eu digo que não tem nova política, tem a política feita dessa maneira.

Acho que por vezes sou parlamentar, porque eu estou fazendo uma prática parlamentar; mas acho que por vezes sou muito mais uma militante fazendo uma experiência parlamentar. Então, é uma elaboração diária, e nessa relação com a favela tem a linguagem que você vai usar, tem toda uma dinâmica de confusão em relação aos papéis institucionais dos poderes Executivo e Legislativo, essa mesma relação fisiológica dos políticos de direita e de centro-direita, que historicamente contaminaram essa relação. Então, existe uma tentativa, o tempo todo, eu acho, de anunciar que há uma diferença. É a linguagem, é a tentativa dessa articulação, misturando até com a chegada da Covid-rge da pandemia.

As favelas se organizaram para trazer ajuda humanitária e, no Parlamento, conseguimos consolidar a pauta da favela. Acho que foi assim nesse período de pandemia, foi o momento em que a gente conseguiu, com sucesso, pautar a favela numa dinâmica institucional; e fazer com que a favela pautasse a Alerj. A partir disso você tem uma relação favela $\times$ universidade,

\footnotetext{
${ }^{16}$ Organização Social de Saúde.

${ }^{17}$ Ver: <http://www.alerj.rj.gov.br/Visualizar/Noticia/50079>.
} 
favelados na universidade e ajuda humanitária, todos articulados com um poder da república pautado pela favela, que financia uma ação de impacto na favela real - como por exemplo, os 20 milhões de reais que a Alerj doa, da sobra do seu fundo, para a Fiocruz. As doações feitas para a Universidade Federal do Rio de Janeiro (UFRJ), por exemplo, para a produção de equipamentos, de respiradores. Então, são os centros de pesquisa, articulados com a favela, a favela pautando o Parlamento, e a gente conseguindo consolidar projetos de lei em que a favela tem uma centralidade impressionante.

\section{A pedagogia do mandato}

Nessa relação entre favela e Alerj, o feminismo negro aparece sob outra lógica. Quando eu preciso falar para ocuparem o nosso mandato, é porque está muito contaminado de uma lógica hierárquica própria de nossa sociedade. Eu falo sempre como é pedagógico o espaço de nossas reuniões com a favela. Então, não precisa falar sobre feminismo, mas se trata de ocupar um espaço. Por exemplo, houve uma reunião com mulheres de vários municípios da Baixada, e eu me emocionei demais ao ver a mulherada falando de política, dizendo que está produzindo uma ação no seu território para crianças e jovens, ou falando do seu empreendimento. É o feminismo na veia. Talvez a dificuldade de muitas feministas, por exemplo, seja não compreender esses tempos, esses ritmos, essa sensibilidade, porque não é só linguagem. Acho que o feminismo negro contribui também para isso.

Não é simples, não é fácil, tem muito tensionamento na relação com o Parlamento, porque a conjuntura não é nossa, o ambiente parlamentar no Brasil não é nosso, é adverso, e vamos tentando lidar com esse processo. Mas a gente vai vencendo, vai dando um drible aqui, outro drible ali, e chega sim. Eu me preocupo muito porque é um espaço de partido e de Parlamento. Por isso eu fiz tanta questão para garantir que a gente tivesse o conselho político, para não deixar a gente perder o norte. Porque se perder isso, para mim, eu acho que não faz sentido. Por isso, eu gosto muito de parafrasear o Betinho quando se referia ao Ibase: para continuar fazendo sentido, não pode perder a dimensão do sonho, tem que ter utopia. 